\title{
Библейское повествование о потопе в контексте древних ближневосточных памятников
}

\author{
диакон Павел Цыбульский \\ Chrześcijańska Akademia Teologiczna w Warszawie, Polska \\ ORCID: 0000-0002-5555-3548 \\ pavtsy@prihod.info
}

deacon. P. Tsybulski, The biblical history of the flood in the context of Ancient Near Eastern literature, Elpis, 22 2020: 87-90.

diak. P. Tsybulski, Biblijna historia o potopie w kontekście starożytnych zabytków na Bliskim Wschodzie, Elpis, 22 2020: 87-90.

\begin{abstract}
The biblical story of the flood has close affinities with other Middle Eastern literature. The story of the flood is found in the Sumerian and Akkadian literary monuments. They show considerable similarity to the biblical story of the flood, both in form and in content. However, there are also differences. The main difference is monotheism in the biblical story and polytheism in most ancient literary monuments.
\end{abstract}

\begin{abstract}
Streszczenie: Biblijna historia o potopie jest ściśle związana z inną literaturą Bliskiego Wschodu. Opowieść o potopie pojawia się w sumeryjskich i akadyjskich zabytkach. Wykazują one znaczne podobieństwo do biblijnej historii potopu, zarówno w formie, jak i w treści. Istnieją jednak między nimi różnice. Główną różnicą jest monoteistyczna nauka w opowieści biblijnej. Politeizm zaś jest charakterystyczny dla większości starożytnych zabytków literackich.

Аннотация: Библейское повествование о потопе находится в тесной связи с другими памятниками ближневосточной литературы. Сказание о потопе уходит корнями в глубь веков, что показывает наличие повествования в шумерских и аккадских памятниках. По форме, и по содержанию имеют они немалые сходства с библейским повествованием о потопе. Также имеют различия, где главным отличием является монотеистическое учение в библейском рассказе, так как в большинстве древних памятников литературы встречается многобожие.
\end{abstract}

Keywords: theology, Old Testament, the flood

Slowa kluczowe: teologia, Stary Testament, potop

Ключевые слова: богословие, Ветхий Завет, потоп

\section{Введение}

В 19 веке происходят события имеющие огромное значение для библеистики. Этот век был ознаменован крупными открытиями на территории библейских стран, среди которых - находка и расшифровка древних текстов. Исследования древних текстов предоставляют нам новые сведения для текстологических размышлений, что приводит к новым открытиям в области библеистики. Стало ясно, что существует множество древних литературных параллелей к Священному Писанию Ветхого и Нового Завета.

Как утверждает учений Самюэль Крамер, семиолог и шумеролог, «сегодня мы можем с уверенностью сказать, что Библия возникла не мгновенно - отнюдь не как некий искусственный цветок, выросший на пустом месте. Она уходит корнями в глубь веков, впитывая в себя соки всех соседних стран. И по форме, и по содержанию книги Библии имеют немалое сходство с литературными произведениями древнейших цивилизаций Ближнего Востока» (Afanas'eva, s. 45). Изучение таких древних литературных памятников помогает ученым в лучшем понимании смысла Священного Писания и культурной среды, в котором оно создавалось.
Данный реферат посвящен библейскому повествованию о потопе в контексте древних ближневосточных памятников. Поскольку библейское повествование о потопе многим хорошо известно (Быт. 6-9), следует акцентировать внимание именно на контексте библейского сказания о потопе в древних памятниках Ближнего Востока.

\section{Шумерское повествование о потопе}

Хранитель клинописной коллекции Британского музея Джордж Смит, отправившись в экспедицию на холм Куюнджик, где когда-то была расположена Ниневия, нашел несколько тысяч глиняных табличек. В числе этих табличек была обнаружена вторая половина рассказа о Всемирном потопе, которая оказалась частью истории вавилонского героя Гильгамеша. Древний эпос был записан на двенадцати глиняных табличках. Позже была найдена и другая вавилонская поэма о потопе, и спустя время ещё более древний фрагмент об этом событии на шумерском языке, текст которого датируется 3 тыс. до. н. э (Afanas'eva, s. 43-44). 
Месопотамские версии сказания о потопе находятся в опубликованной Арно Пебелем в 1914 г. шумерском табличке (Из Ниппурской коллекции Музея Пенсильванского университета), в вавилонском эпосе о Гильгамеше («О все видавшем») и в сказании об Атрахасисе («Когда боги, подобно людям»). Но из опубликованного Арно Пебелем шумерского фрагмента, становится очевидным, что вавилонская версия сказаний о потопе, восходит к шумерской (Akimov, 2005, s. 139).

Шумерский фрагмент текста, который относится к 3 тысячелетию до н. э., дошел до нас в поврежденном виде. До нынешнего времени эта табличка остается уникальной, так как археологи не нашли дублирующего рассказа, чтобы дополнить недостающий текст. Шумерское повествование о потопе предваряет упоминание, о том, как было устроено мироздание:

«Когда Ан, Энлиль, Энки и Нинхурссага

Черноголовых сотворили,

Четвероногие твари множились...» (Sinilo, 1998, s. 77).

Затем следует перечисление допотопных городов и их царей перекликаясь с шумерским «Царским списком», где говорится о весьма необычайно длинном царствовании в этот период времени до потопа. Подобная особенность - это долгая жизнь библейских допотопных патриархов (The context of Scripture, s. 514).

Следующий фрагмент текста сильно поврежден и не совсем становится понятным причина уничтожения человечества богами. Но бог Энки сочувствует людям и собирается их предупредить об опасности (The context of Scripture, s. 514).

Далее, после утраченной части текста, появляется царь Зиусудра. Царь Зиусудра с его кораблем - это прообраз библейского Ноя с его ковчегом. Зиусудру призывает божественный голос из стены и предупреждает о решении богов сотворить потоп, чтобы уничтожить человечество:

«Уголок стены, скажут тебе слово, мои слова прими со вниманьем!

На то, что скажу я, обрати вниманье!

Потоп пронесется надо всем миром, Семя человеков дабы уничтожить. s. 77).

Таково окончательное решение совета...» (Sinilo,

Скорее всего, Энки, дает указание Зиусудре построить корабль, на котором царь спасается вместе с растениями и животными, которых он взял с собой. Потоп продолжался 7 дней и 7 ночей, после чего, на 8 день потоп стихает и появляется бог Уту. Тогда Зиусудра приносит богу солнца жерты, быка и овцу. В итоге боги Ан и Энлиль даровали Зиусудре жизнь и бессмертие. И подобно богу, его поместили в страну Дильмун, где восходит солнце (Akimov, 2005, s. 139):

«К жизни вечной, подобно богу, его избрали,

Тогда они Зиусудру, царя

Всех тварей, семени человечества спасителя,
В страну перехода, в страну Дильмун, там, где Уту встает,

Там его поселили» (Sinilo, 1998, s. 78).

Шумерское повествование о потопе является древнейшим и ценнейшим памятником сказаний древних народов. Этот шумерский текст послужил первоисточником для двух других вавилонских сказаний о потопе и параллелью к библейскому повествованию о потопе.

\section{Эпос об Атрахасисе}

Из шумерской мифологии и литературы в аккадскую попало сказание о потопе, которое дало две вавилонские версии. Это сказание об Атрахасисе и эпос о Гильгамеше. Первый эпос включает также миф о сотворении человечества, на которое затем по воле богов обрушиваются бедствия (Sinilo, 1998, s. 122).

«Эпос об Атрахасисе» (имя Атрахасис означает «умудренный знанием», «превосходящий мудростью»), или «Когда боги, подобно людям...», датируется старовавилонским периодом и впервые был опубликован оксфордскими учеными У. Г. Лэмбертом и А. Р. Миллардом в 1969 г. (Akimov, 2005, s. 139).

Этот эпос объясняет создание человека, предназначенного для облегчения труда божеств. Человек создан, чтобы возложить на него «бремя богов» и для их пропитания (жертвоприношения). И судя по тексту, человек справлялся с этим бременем до того времени, когда первый людской шум встревожил хозяина земли Энлиля и людей стало слишком много (Afanas'eva, s. 66).

В эпосе описывается такой людской шум, который мешал спокойно спать Энлилю:

«Страна разрослась, расплодились люди.

Как дикий бык, ревут земли.

Бог встревожен громким шумом.

Энлиль слышит людской гомон,

Богам великим молвит слово:

«Шум человека меня донимает,

Спать невозможно в таком гаме!»» (Afanas'eva, s. 66).

И как божественный ответ на шум растущего населения - это попытки уничтожить или сократить количество людей. Шум растущего людского населения угрожал покою божеств, который боги хотели обеспечить себя создавая человека. Это уничтожение, установленное Энлилом, принимает несколько последовательных форм - мор, голод (The context of Scripture, s. 450-451).

Спасение от этих бедствий происходило, благодаря Атрахасису, которому помогал бог Энки:

«Некто, мудрейший из всех, Атрахасис -

Наставлял Атрахасиса Энки-владыка, -

Он говорил со своим богом,

И бог давал ему наставленья...» (Akimov, 2005, s. 139). 
Бог Энки не просто так помогал ему, а по молитвам Атрахасиса, как мудрейшего человека жившего по наставлениям божьим. На праведности и ревностной молитве Атрахасиса в сказании подчеркивается особое внимание:

«Атрахасис молился своему богу,

Приношения у ногам его ставил.

Каждый день он горестно плакал,

Вместе с зарей приносил ему жертвы,

Он заклинал бога в молитвах,

Он ждал знамения и сновиденьи...

Он приходил к храму бога, s. 66).

Перед храмом бога сидел и плакал» (Afanas'eva,

Кульминацией всех бедствий становится всемирный потоп, но, как и в других рассказах о наводнениях, его цель не состоялась из-за выживания героя потопа - Атрахасиса, через вмешательство Энки (The context of Scripture, s. 450).

Энки повелевает Атрахасису построить корабль, взять еду, семью, животных. И после строительства начинается потоп, который бушевал 7 дней и 7 ночей:

«Взревел Адад в черной туче,

Забушевали яростно ветры,

Лопнул канат, зашвыряло судно.

Ураганом потоп пронесся,

По людям прошелся, подобно битве,

Один не может узнать другого,

Увидеть друг друга в разрушенье.

Как бы ревущий, потоп бушует,

Как дикий осел, завывает ветер» (Sinilo, 1998, s. 122).

После спасения Атрахасис приносит жертву, на запах которой слетаются боги. Они решают обратиться к Энки и Мами-Нинту с просьбой создать новое человечество, а Атрахасису даруют бессмертие (Akimov, 2005, s. 139).

Мифологема ${ }^{1}$ в сказании об Атрахасисе выглядит следующим образом: греховность человечества - недовольство бога - кара - молитвы заступника-праведника - отведение кары (Afanas'eva, s. 66). Подобные схемы мы можем рассмотреть в Библии, в Моисее, Аврааме - как молитвенниках-заступниках своего народа. И конечно же мудрец Атрахасис является прообразом библейского праведника Ноя.

\section{Эпос о Гильгамеше}

Эпос о Гильгамеше заслуженно является самой известной литературной реликвией древней Месопотамии. Его развитие может быть прослежено от шумерских повествований («Сказание о Зиусудре») посредством последовательных аккадских переводов,

\footnotetext{
1 Мифологема - это таинственное знание поэта о сути вещей, когда он произносит Слово, еще не догадываясь сам, что за ним скрывается.
}

к окончательной канонической версии в двенадцати таблицах (The context of Scripture, s. 458). По словам С. Н. Крамера, «с точки зрения раскрытия человеческой психологии и по своей драматичности «Эпос о Гильгамеше» не имеет себе равных в вавилонской литературе» (Akimov, 2013, s. 177).

Главная тема эпоса - это герой, обреченный на поиски вечной жизни. Имя «Гильгамеш» встречается в шумерском «Царском списке», где он обозначен как пятый царь города Урука, первой послепотопной династии (Akimov, 2013, s. 177-178).

Из многих библейских параллелей, представленных в «Эпосе о Гильгамеше», ни одна из них не является более многочисленной или более известной, чем табличка 11 с его месопотамской версией истории о потопе. Это самая сложная версия истории, которая была рассказана более кратко уже в других контекстах, как шумерском, так и аккадском (The context of Scripture, s. 458).

В поисках вечной жизни, Гильгамеш отправляется к Утнапишти, который пережил потоп, и боги уже даровали ему бессмертие. (Утнапишти - это имя, аккадский эквивалент шумерского имени Зиусудра) (Sinilo, 1998, s. 122). И Утнапишти рассказывает Гильгамешу о том, как бог Энки обращаясь к нему через стену, давал указания о строительстве корабля:

«В пятеро суток заложил я кузов:

Треть десятины площадь, борт сто двадцать локтей высотою,

По сто двадцать локтей края его верха.

Заложил я обводы, чертеж начертил я:

Шесть в корабле заложил я палуб,

На семь частей его разделивши ими,

Его дно разделил на девять отсеков...

Нагрузил его всем, что имел я,

Нагрузил его всем, что имел серебра я,

Нагрузил его всем, что имел я злата,

Нагрузил его всем, что имел живой я твари,

Поднял на корабль всю семью и род мой,

Скот степной и зверье, всех мастеров я поднял» (Akimov, 2005, s. 140-141).

Далее Утнапишти вспоминает дни потопа:

«Ходит ветер шесть дней, семь ночей,

Потопом буря покрывает землю.

При наступлении дня седьмого

Буря с потопом войну прекратили...» (Sinilo, 1998, s. 123).

Когда же потоп закончился, Утнапишти рассказывает:

«Я открыл отдушину - свет упал на лицо мне,

Я взглянул на море - тишь настала,

И все человечество стало глиной!

Плоской, как крыша, сделалась равнина.

Я пал на колени, сел и плачу,

По лицу моему побежали слезы» (Sinilo, 1998, s. 124).

Затем после бури, Утнапишти выпускает голубя, ласточку и ворона, что сразу же напоминает прообраз 
Ноя, когда он трижды выпускал птиц. Бог Энки умилостивил Энлиля, чтоб он не карал человека. И Энлиль даровал Утнапишти вечную жизнь и поселил его «при устье рек» (Sinilo, 1998, s. 124).

«Доселе Утнапишти был человеком,

Отныне ж Утнапишти нам, богам, подобен,

Пусть живет Утнапишти при устье рек, в отдаленье» (Akimov, 2005, s. 141).

Таким образом, как отмечает Г. В. Синило о том, что при сопоставлении шумерских героических сказаний («Сказание о Зиусудре») и вавилонского эпоса о Гильгамеше, «старый сюжет получает новое поэтическое дыхание за счет энергичного сжатия текста и одновременно его динамизации психологизации» (Sinilo, 1998, s. 120-121).

\section{Заключение}

В заключении следую сказать о том, что библейское повествование о потопе находится в тесной связи с другими памятниками ближневосточной литературы. Сказание о потопе уходит корнями в глубь веков, что показывает наличие повествования в шумерских и аккадских памятниках. Они и по форме, и по содержанию имеют немалые сходства с библейским повествованием о потопе, но также имеют различия, где главное различие - это монотеистическое учение в библейском рассказе. Благодаря Библии сохранился самый совершенный вариант истории о всемирном потопе, в отличие от других литературных произведений древнейших цивилизаций Ближнего Востока.

\section{Bibliografia}

Bibliâ. Svâsennoe Pisanie Vethogo i Novogo Zaveta. (1992.). Moskva: Izdanie Moskovskoj Patriarhii. [Библия. Священное Писание Ветхого и Нового Завета. (1992.). Москва: Издание Московской Патриархии].

The context of Scripture. (2003). (editor Hallo W. W). Leiden, The Netherlands Vol. 1.

Akimov, V.V. (2013). Biblejskaâ Kniga Ekkleziasta i literatura mudrosti Drevnej Mesopotamii. (s. 296). Minsk: Kovčeg. [Акимов, В.В. (2013). Библейская Книга Екклезиаста и литература мудрости Древней Месопотамии. (s. 296). Минск: Ковчег].

Akimov, V.V. (2005). Biblejskoe povestvovanie o potope (Byt. 6-9) i drevnââ bližnevostočnaâ literatura. W: Materialy 10 Meždunarodnyh Kirillo-Mefodievskih čtenij, posvâsennyh Dnâm slavânskoj pis'mennosti i kul'tury, 24-26 maâ 2004 g. Čast' 1. Minsk. [Акимов, В. В. (2005). Библейское повествование о потопе (Быт. 6-9) и древняя ближнево- сточная литература. W: Материаль 10 Международных Кирилло-Мефодиевских чтений, посвященных Дням славянской письменности и культуры, 24-26 мая 2004 г. Часть 1. Минск].

Afanas'eva, V.K. Biblejskie sûžety v šumerskoj literature. W: Mir Biblii. Illûstrirovannyj Al'manah Biblejsko-bogoslovskogo Instituta sv. apostola Andreâ. Vypusk 8. Moskva. [Афанасьева, В.К. Библейские сюжеты в шумерской литературе. W: Мир Библии. Иллюстрированный альманах Библейско-богословского Института св. апостола Андрея. Выпуск 8. Москва].

Sinilo, G.V. (1998). Drevnie literatury Bližnego Vostoka i mir Tanaha (Vethogo Zaveta). Minsk: Izdatel'skij centr «Èkonompress». [Синило, Г.В. (1998). Древние литературы Ближнего Востока и мир Танаха (Ветхого Завета). Минск: Издательский центр «Экономпресс»].

Rozmiar artykułu: 0,5 arkusza wydawniczego 